\title{
Memórias de um sargento de milícias: ninguém aprende samba no colégio
}

Fecha de recepción: 7/6/2021. Fecha de aceptación: 1/7/2021.

\section{Resumo}

Este artigo sugere a hipótese de lermos Memórias de um sargento de milícias como um romance de formação para o homem livre remediado carioca de meados do século XIX. Para isso, contudo, recupera o ensaio de referência de Antonio Candido, "Dialética da malandragem", para argumentar que o crítico sobrepõe um malandro posterior, construído na cultura brasileira a partir dos anos 1920/1930, ao capadócio, também presente no romance, mas não como personagem principal. Se prospera a leitura de um romance de aprendizagem, o que estaria aprendendo o leitor "brasileiro" de então? Como se distanciam a formação do indivíduo burguês representada em narrativas do centro do capitalismo, mormente Inglaterra e França, e a formação do homem livre representada na periferia do capitalismo?

Palavras-chave: romance de formação; malandro; indivíduo burguês; Antonio Candido

Memoirs of a militia sargeant: no one learns samba at school

\begin{abstract}
This article suggests the hypothesis of undesrtanding Memoirs of a militia sargeant as a Bildungsroman for the free man in the Rio de Janeiro from 1850s. Therefore, however, it reads the Antonio Candido’s reference essay, "Dialética da
\end{abstract}

1 Professor de Literatura Brasileira (UFRGS). E-mail: guto.leite82@gmail.com Pesquisador na área de canção popular, modernidade e cinema. Compositor de dois álbuns autorais e poeta de seis livros publicados. 
malandragem", to argue that the critic overlaps an ulterior figure, the "malandro", built in Brazilian culture in the 1920s/1930s, on the "capadocio", also present in the novel, but not as the main character. If this interpretation as a Bildungsroman is reasonable, what would that "Brazilian" reader was learning? How they differ the bourgeois represented in narratives of the capitalism's center, mainly England and France, and the free man represented in novels from this capitalism's periphery?

Keywords: Bildungsroman; malandro; bourgeois; Antonio Candido

Aos domingos, entre 27 de junho de 1852 e 31 de julho de 1853, numa seção chamada "Pacotilha", do jornal liberal ${ }^{3}$ Correio Mercantil, foi publicado o romance folhetinesco de Manuel Antônio de Almeida (1830-1861), Memórias de um sargento de milícias, que ganharia versão em livro, em dois tomos, editada em 1854 e 1855. A princípio, o romance não despertou maior atenção de leitores, críticos e pesquisadores, eclipsado por produções como a de José de Alencar (1829-1877), seu contemporâneo justo, e Machado de Assis (1839-1908), que chegou a trabalhar, quando jovem, com o autor das Memórias; a morte precoce de Almeida, com 31 anos, com publicação modesta - além deste romance, crônicas, artigos de opinião, críticas e uma opereta póstuma -, é também fator decisivo para sua falta de notoriedade. Mais de um século depois, em 1970, Antonio Candido, talvez o crítico literário brasileiro de maior projeção no século XX, publica "Dialética da malandragem" e alça o romance a um lugar de mais destaque na história literária nacional. A ligeireza de sua construção e a fluidez ao sabor da pena se transformam, na visão do crítico, na elaboração de certo modo de ser brasileiro:

Esta [libertação em relação à ideologia das classes dominantes] se articula com uma atitude mais ampla de tolerância corrosiva, muito brasileira, que pressupõe uma realidade válida pra lá, mas também pra cá da norma e da lei, manifestandose por vezes no plano da literatura sob a forma de piada devastadora, que tem certa nostalgia indeterminada de valores mais lídimos, enquanto agride o que, sendo hirto e cristalizado, ameaça a labilidade, que é uma das dimensões fecundas do nosso universo cultural (Candido, 2004, p. 45)

Descontada a ideologia do comentário de Candido, que converte "carioca" em "brasileiro" "modo de ser de classe em modo de ser nacional” (Schwarz, 1987, p. 50) e generaliza um comportamento historicamente determinado (ibíd., p.154s.), embora continuidades dessas estruturas possam e devam ser acompanhadas, seu ensaio é considerado um ponto de virada na crítica materialista brasileira

2 A 'Pacotilha" era uma seção preponderantemente humorística, em contraste com o teor sério e empenhado do jornal. Como esperado, a matéria trabalhada humoristicamente correspondia a aspectos reconhecíveis da vida carioca de então (Jarouche, 2006, 18ss.).

3 Há inúmeros indícios históricos e ficcionais da diferença não muito notável entre conservadores e liberais, os dois partidos da monarquia constitucional brasileira de meados do XIX. A discórdia se mostrava basicamente quanto à população portuguesa radicada no país recém saído de sua independência: os liberais atuavam contra os portugueses em posições-chave na vida do Império e contra um suposto risco de "regressismo", que seria o Brasil voltar a ser colônia de Portugal. Há no Partido Liberal brasileiro e em seu principal jornal uma pauta de brasilidade, portanto. Cabe notar que as relações estabelecidades até aqui - seriedade / humor, conservador / liberal / lusitanidade / brasilidade - estão no cerne do debate deste artigo. 
(Arantes, 1992) em razão da pertinência de associar um comportamento recorrente à maioria das personagens do livro e de seu narrador, em terceira pessoa, mas bastante pessoalizado, a uma forma enviesada de conceber as instituições, a lei, as instâncias da ordem, plasmada há cento e setenta anos, mas cujos desdobramentos ainda são possíveis de perceber. 0 ensaio de Candido é entendido também como realização fundamental da acumulação crítica brasileira, no sentido de performar uma perspectiva local autônoma frente a exercícios crítico-teóricos estrangeiros.

Um parêntese um tanto decisivo. É bom considerar que a relação que se dá entre crítico, forma crítica e forma literária, neste caso, é das mais complexas. O romance, friso, de meados do XIX, foi escrito quando os termos "malandro" e "malandragem" eram muito residuais - o termo "malandro" é usado uma única vez no romance, está dicionarizado apenas como "malandrim" (Silva \& Bluteau, 1789; Pinto, 1832) e é raro em outros livros do período. Havia figuras de subversão análogas, chamadas de "capadócios", geralmente associadas ao recurso da violência, do crime, das armas, ou de "vadios", "patuscos", identificadas à vida sem ofício - esses termos aparecem no romance e em outros romances do período com alguma frequência. Mais tarde, nos anos 1920 e 1930, sobremodo em função da música popular, da parcela progressista da intelectualidade e de medidas estatais que tornariam o malandro símbolo nacional, a palavra entraria em uso corrente e se ressignificaria. Candido, nascido em 1908, testemunhou, portanto, essa transformação e redigiria seu ensaio, não só posteriormente a formulações críticas decisivas quanto a temas contíguos ao da malandragem, como Casagrande \& senzala (1933) e Raízes do Brasil (1936), como também ao próprio insucesso de um Estado cordial moderno na periferia do capitalismo ${ }^{4}$, com o começo da Ditadura Civil-Militar, em 1964.

Faço este arco para discriminar o quanto há de intervenção no ensaio de Candido, que talvez apostasse num herói popular contra as forças violentas e autoritárias da ordem - no romance, na figura de um major, Vidigal -, e o quanto o malandro que ele identifica não seria exatamente uma personagem dos anos 1850, mas uma construção posterior. Todo gesto dialético é um tanto anacrônico - fixar as formas a um tempo determinado é paixão formalista -, mas caberá comentar mais adiante as implicações do anacronismo de Candido em sua leitura do romance.

Haja vista que estávamos na primeira ou na segunda década de produção bemsucedida de romances no país ${ }^{5}$, não é exagero afirmar que as Memórias de um

40 crítico de cinema Ismail Xavier aponta o quanto a versão fílmica de Macunaíma (1969), de Joaquim Pedro de Andrade, revisa a vitória malandra, primeiro rompendo sua constituição com componentes caipiras - "Perto do fim, as imagens do herói solitário assumem um tom patético, com Macunaíma a compor a figura do Jeca, a máscara do caboclo sem charme substituindo a malícia do malandro." (Xavier, 2014, p.320) -, mas também alterando o enredo da rapsódia de Mário de Andrade, matando o herói, e não transformando-o em estrela. Cabe dizer que Candido entende Macunaíma como ponto-de-chegada, no que tange à realização simbólica do malandro, da figura de Leonardo, no romance de Almeida (Candido, 2004, p.45).

5 Os romances no Brasil começam em 1822 ou 1826, havendo divergência sobre o que se considera um romance, mas decerto um marco de estabelecimento desta linguagem conectando autores e público está em A moreninha, de Joaquim Manuel de Macedo (1844). Para um levantamento minucioso do romance brasileiro, consutar: www.caminhosdoromance.iel.unicamp.br [consultado em 16/06/2020]. 
sargento de milícias educaram o leitor para a forma romance e mesmo para a ficção ${ }^{6}$. Recursos como o humor, uma conexão próxima entre o que se reconhecia como vida cotidiana e a matéria do romance e a construção desse narrador sibilino, que julga e faz troça das personagens da história, podem ser consideradas boas estratégias nessa educação. Mas e se aventássemos que o romance educa também para um modo de ser da "gente livre modesta" (Candido, 2004, p.27) carioca de meados do dezenove? Isto é, que o romance ensina como deve se comportar o homem livre por aqui?

Trato, evidentemente, do romance de aprendizagem ou do romance de formação, termos que tantas vezes se misturam e se esvaziam, e que compõem o tema deste dossiê. Não interessa a versão mais ingênua da noção, depreendida de maneira imediata por Morgenstern sobre Os anos de aprendizado de Wilhelm Meister (1795), de Goethe, mas sua notável qualificação a partir das formulações de Lukács em A teoria do romance, que esclarece:

De um lado, portanto, essa interioridade é um idealismo mais amplo e que se tornou com isso mais brando, mais flexível e mais concreto e, de outro, uma expansão da alma que quer gozar a vida agindo, intervindo na realidade, e não contemplativamente. Assim, essa interioridade situa-se a meio caminho entre idealismo e Romantismo, e ao tentar em si uma síntese e superação de ambos, é rejeitada por ambos como transigência (Lukács, 2000, p. 139)

À luz ainda das palavras de Lukács, poderíamos pensar o romance de formação como uma narrativa de afinação do indivíduo burguês a seu mundo, percebido como tal em tempo relativamente recente, orientada para certa miragem de completude. Livre, porém enquadrado. Único, mas similar a todos os outros. Subjetivo, mas objetivamente compreendido nas funções disponíveis na sociedade. Não à toa que se trata de narrativa desde o nascimento ou infância e culmine na integração a um ofício e no casamento, instituições que apontam para a nação, como fim, nas duas acepções, da vida burguesa. Podemos, na contraluz, divisar o crescendo das ambivalências desde Meister, acrescido das diferenças entre centro e periferia, e aventar que "essa concepção de indivíduo livre e autônomo é um dos múltiplos resultados da generalização da forma mercadoria ao longo do processo de expansão do capitalismo, em que está alicerçado o estabelecimento da ordem burguesa" (Otsuka, 2007, p. 115), não enxergando, assim, oposição entre idealismo e Romantismo, mas um grande arco entre as Grandes Navegações e a metade final do século XX. Isto é, no fim da individualidade como consequência da maturação do mundo burguês, refratada nas diversas instituições desse mesmo mundo, e na nação, em última instância, está a indistinção estrutural da mercadoria ou mesmo a polivalência metafísica do capital ele mesmo, cada vez mais independente de seu lastro material, cada vez mais ficcional. Os romances de formação estariam, com isso, ou operando nessa composição ideológica, ou acusando uma das ideologias axiais da sociedade burguesa. Se considerarmos

6 As relações entre a ficção e a educação para a vida burguesa, eixo deste ensaio, são trabalhadas por Catherine Gallagher (2009), em "Ficção". 
ainda a maneira com que a noção de Bildungsroman foi importada, desmarcada, modificada, fetichizada, especificamente a partir da célebre vida cultural alemã do último quarto do XVIII, as transformações sofridas pela forma crítica se tornam indícios das dificuldades de tratamento dialético da questão, que consistiria no desenvolvimento desigual e combinado da sociedade burguesa.

Lido ingenuamente, Memórias de um sargento de milícias não fugiria ao roteiro. Leonardo é concebido no navio de Portugal para o Brasil, nasce no Rio de Janeiro, é batizado, vai à escola, torna-se coroinha e vislumbra o casamento. Seus planos são contrariados por um pequeno vilão e o protagonista se afasta ao máximo das esferas da ordem, vivendo como agregado numa parentela regida por duas senhoras e se enamorando de uma jovem. Consegue um ofício e o perde, em seguida é preso pelo major Vidigal, o vilão maior, que persegue antes o pai do protagonista, e transformado em granadeiro - profissão de alto risco e que, com efeito, bloqueava sua integração às instituições burguesas. Para piorar, ao desobedecer e enganar Vidigal, seu então chefe, é preso. No desfecho do romance, pela Providência - o capítulo se chama "A morte é o juiz" - e pelo favor, as providências, os empenhos, de três senhoras, Leonardo é solto, promovido e se casa (sua promoção é condição para seu casamento), por hipótese (em que nenhum leitor brasileiro menos ingênuo acreditaria), deixando para trás o tempo de arruaça.

Reduzi o romance à linha narrativa do protagonista, mas sabemos que é muito mais do que isso - somente metade dos capítulos do livro são centrados em Leonardinho, cerca de vinte e cinco. Primeiro porque ao fundo acompanhamos também, em parte, a história do pai do protagonista (ao menos cinco capítulos são centrados nele), também chamado Leonardo, meirinho (oficial de justiça), mas de alcunha Pataca, uma moeda que equivalia a 320 réis, preço de sua demanda ao final da carreira - notável que tenha um homem-dinheiro no romance, especialmente se pensarmos no dinheiro como a mercadoria metamorfa por excelência. Também acompanhamos o mundo que cerca e que afiança as peripécias do protagonista, seu Compadre, que o cria, sua Comadre, que zela por ele, especialmente após a morte do padrinho, e um Tenente-Coronel, não tão fisicamente presente no romance mas de quem emana, no limite, a proteção mais decisiva quanto ao destino do jovem na primeira parte da obra. Temos ainda capítulos dedicados a figuras de antagonismo (Vidigal, sobretudo, mas também José Manuel e Mestrede-Reza) e de diferença (D. Maria, Luisa e seu núcleo de proprietários, Vidinha e seu núcleo de marginalizados), além de passagens dedicadas a festas, costumes e figuras de época ${ }^{7}$.

Com essa "expansão" percebemos logo que parte importante das ações de Leonardo não são exercidas por ele, por mais contraditório que isso possa parecer. o Compadre o acolhe quando é abandonado pelos pais (Leonardo e Maria), a Comadre, quando ouve notícias ruins do Leonardo pai, passa a interferir em sua formação, acabando por introduzi-lo na casa de D. Maria, que renderá casamento;

7 A prosa mesma do romance destoa da orientação de "utilidade" do universo burguês (Moretti, 2014: pp. 4346), mas não cabe desenvolver aqui esta leitura. 
tudo sob os cuidados do oficial superior do rei, que às vezes se faz presente em ofertas ou respondendo a demandas. Seu arco de integração ao mundo burguês não se dá por ações suas; muito diferente, portanto, de como é representada a figura de indivíduo burguês em literaturas do centro. A propensão de Leonardo é antes pela desordem e, quando age "de sua cabeça", costuma atrasar os planos de seus padrinhos.

Por diversos caminhos, parece estar desmontada a cultura do trabalho, "maior conquista simbólica da burguesia como classe" (Moretti, 2014, p. 50). Leonardo trabalha na ucharia real, como granadeiro e, ao fim, como sargento de milícias. $O$ compadre é barbeiro, a comadre é parteira, temos sacristão, professor, meirinho etc. ${ }^{8}$ Há ofícios por toda parte, mas só os mais ingênuos escoram seu futuro naquilo em que trabalham. A metodização, os planos, os esforços alinham-se frequentemente para "arranjar-se" - expressão que no romance tem o sentido de "se dar bem", "resolver-se" - e não para ascender por ofício regular. Para seguir com Moretti, a ideia de que "qualquer um" pode subir na vida parece subvertida, "o mundo é dos espertos”, e mais vale talento do que trabalho, não o inverso (ibíd, p. 91). Ou talvez não valham nem talento nem trabalho, como veremos, e tudo isso seja uma espécie de fábula em que as personagens vivem materialmente suas vidas.

Em Memórias de um sargento de milícias, não só no enredo do protagonista, mas também nas histórias de outras personagens e na maneira como o narrador as relata, a forma parece traiçoeira quando convidada a se posicionar sobre se é bom ou ruim o que se apresenta como ordem ou desordem ${ }^{9}$ - como bem notou Candido, a forma do romance é análoga ao movimento de narrador e personagens; a anedota de que o autor teria escrito alguns capítulos "na copa do chapéu” (Almeida, 2006, p. 357) só reforçam o movimento geral. Patifes se dão bem, depois se dão mal. Pessoas generosas, que descobrimos terem sido canalhas no passado, morrem subitamente. Figuras famosas por sua benevolência agem e manipulam na surdina um sem número de gentes. Personagens são punidas e restam impunes quase indistintamente. Ninguém age sem motivação pessoal, esta é a regra, salvo aqueles que, como nosso protagonista, só querem ver o circo pegar fogo, quando criança, e arranjar-se com Luisa, quando jovem, e ainda não aprenderam, com efeito, como as coisas funcionam. Nos termos de Candido:

O cunho especial do livro consiste numa certa ausência de juízo moral e na aceitação risonha do "homem como ele é", mistura de cinismo e bonomia que mostra ao leitor uma relativa equivalência entre o universo da ordem e da desordem; entre o que se poderia chamar convencionalmente de o bem e o mal (Candido, 2004, p. 33)

8 Embora discorde de algumas das conclusões do autor em relação às Memórias de um sargento de milícias, para um panorama da ascensão social no romance brasileiro do segundo reinado, Boucinhas (2016).

9 Se tomarmos a ordem como o mundo institucionalizado e a desordem como o mundo desinstitucionalizado, pelo viés da "gente livre modesta" (sabemos que nunca é tão estanque), as Memórias realizam uma dança interessante entre a inevitável, mas adiada, integração ao universo burguês, e a manutenção de privilégios oriundos de um mundo senhorial e escravista; como se a distância para o centro desse margem para sucessivos avanços e recuos da elite periférica, buscando extrair o melhor possível pelo tempo possível. Não só de cima pra baixo, esse princípio se refrata por aquele mundo que acabara de proibir o tráfico negreiro (1850), mas ainda não libertara os escravizados (1888) 
Em 2004, Edu Otsuka, em um ensaio intitulado “Espírito rixoso”, faz algumas modulações importantes ao ensaio de Candido, duas delas caras a este artigo. A primeira, também movida pelo presente de Otsuka, reintroduzindo a violência, muito amainada no texto de 1970. A segunda, caracterizando uma dinâmica de rixas, que envolve e consome quase todas as personagens do romance em oposições eventuais nunca levadas à última consequência, diferente das vinganças, e que transforma antagonismo de classe em rixa entre os pares (Otsuka, 2007, p. 122). Alguns pontos menos evidentes precisam ser sublinhados. De início, as “manifestações de cunho arquetípico", à la conto da carochinha, na leitura de Candido, ganham notável substância ao serem historicizadas. Todos brincam de brigar porque não podem derrotar definitivamente o outro - "aquele que se forma passando no outro (ou que é ao mesmo tempo que se torna outro), se forma suprimindo-se, isto é, ele se constitui no e pelo ato mesmo de sua desaparição" (Pasta Júnior, 2010, p. 19). Esse comportamento estaria calcado na resistente natureza escravocrata de nossa sociedade - o senhor de escravos é quem é pela existência de seu oposto, o escravo; sistema subordinado a um centro cujas relações já se estabeleciam em termos de classe, e não senhorialmente-, comentada por tantas e tantos, de diversos campos, que incide e bloqueia o processo de individuação. Ou seja, elemento que estrutura a sociedade brasileira de então tornado forma no romance.

Com efeito, a individuação pressupõe a renúncia às gratificações imediatas, imaginando-se cenas no horizonte temporal, em nome da manutenção material da própria existência. Já a atuação desenfreada dos impulsos agressivos nas relações de rixa indica que, no universo social das Memórias, não se encontra pelo menos não com a mesma intensidade - a renúncia pulsional indispensável à constituição do princípio de realidade nos termos das sociedades avançadas. Nesse sentido, o domínio do espírito rixoso sugere uma diferença significativa em relação à subjetividade no sentido definido pela civilização burguesa - e essa peculiaridade do sujeito figurada nas Memórias tem fundamento na organização econômico-social do Brasil oitocentista (Otsuka, 2007, p. 117).

O curto-circuito é espantoso. Otsuka, em certa medida, corrige as leituras de Mário de Andrade e de Candido, que afirmam não haver "gente de cor" no livro, "salvo as baianas da procissão dos Ourives, mero elemento decorativo, e as crias da Casa de Dona Maria, mencionadas de passagem para enquadrar o Mestre de Reza" (Candido, 2004, p. 28), propondo que o cerne de um dos princípios estruturais da obra, a rixa, se apoia num processo inacabado de individuação decorrente da escravidão. Para além de sua hipótese interpretativa, de fato há muito mais negros e negras no romance do que notam Mário de Andrade e Candido: "o caboclo da casa do mangue", a quem o narrador chama de "nojento nigromante"; os músicos barbeiros, "ordinariamente negros"; as baianas citadas pelo ensaísta; também citado o "não pequeno número de negras e negrinhas escravas de $\mathrm{D}$. Maria”, mais a escrava de Luisinha, não mencionada, futura esposa de Leonardo, protagonista da obra.

Outras duas personagens negras, ou afrodescendentes, merecem comentário. A primeira é Vidinha, moça por quem Leonardo vai se apaixonar, no momento 
da história em que ele está mais afastado da esfera da ordem, "lá para as bandas dos Cajueiros". Vidinha é assim descrita pelo narrador:

Vidinha era uma mulatinha de 18 a 20 anos, de altura regular, ombros largos, peito alteado, cintura fina e pés pequeninos; tinha os olhos muito pretos e muito vivos, os lábios grossos e úmidos, os dentes alvíssimos, a fala era um pouco descansada, doce e afinada. (Almeida, 2006, p. 240)

Que não a tomemos por negra, mas mulata, fiados na precisão do narrador, é razoável - mesmo que seja hábito, sendo negro no Brasil, chamar/chamar-se "mulato" ou "pardo" em razão do enorme estigma sofrido pela população negra brasileira (o narrador poderia estar indicando tratar-se de negra livre ao dizer "mulatinha", tal como vai fazer com o "pardo" Chico-Juca, que analisaremos a seguir). Contudo, não é possível obliterar o universo popular que Vidinha evoca, quer por sua oposição na trama à Luisa, herdeira, da elite, quer por seu núcleo ele mesmo, tocando violão, entoando modinhas, vivendo com primos e primas sob os conselhos de duas irmãs, talvez profissionais do sexo de outrora, então senhoras. Chico-Juca, por sua vez, é descrito assim:

O Chico-Juca era um pardo, alto, corpulento, de olhos avermelhados, longa barba, cabelo cortado rente; trajava sempre jaqueta branca, calça muito larga nas pernas, chinelas pretas e um chapelinho branco muito à banda; ordinariamente era afável, gracejador, cheio de ditérios e chalaças; porém nas ocasiões de sarilho, como ele chamava, era quase feroz. Como outros têm o vício da embriaguez, outros o do jogo, outros o do deboche, ele tinha o vício da valentia; mesmo quando ninguém lhe pagava, bastava que lhe desse na cabeça, armava brigas, e só depois que dava pancadas a fartar é que ficava satisfeito; com isso muito lucrava: não havia taverneiro que the não fiasse e não o tratasse muito bem. (Almeida, 2006, p. 152)

Tido por Otsuka como "a própria personificação da desavença cotidiana" (2007, p.110), o homem-rixa, sua figuração no romance é crucial para o argumento que aqui vai se insinuando. Primeiro, por assumir a rixa como ofício - às margem da lei, como o nigromante e a cigana, mas ainda ofício. Um ofício que lhe concedia, por hipótese, longos tempos de ócio mas que trazia não poucos riscos quando em exercício. Quem tinha a "profissão de malandro", nos termos de Moreira da Silva a Claudia Matos (1982, p. 77) - em que se consegue salário sem trabalhar muito, "como certos tipos de funcionário público" -, era Leonardo, aliás, um "arranjo", dito desse modo, obtido por sua madrinha, o arranjo de Leonardo. Segundo, porque o malandro que seria desarmado nos anos trinta pela música popular é tal como o narrador descreve Chico-Juca. Vejamos "Lenço no pescoço" (1933), de Wilson Batista: "Meu chapéu de lado, / Tamanco arrastando, / Lenço no pescoço, / Navalha no bolso. / Eu passo gingando, / Provoco e desafio / Eu tenho orgulho de ser tão vadio." Sobre este malandro se depositará seu simulacro, sem tamanco, sem lenço, sem navalha, mas com violão e lápis (!) (embora no Distrito Federal fosse menor, o analfabetismo no Brasil rondava os 60\%), como em "Rapaz folgado", de Noel Rosa. Entre um malandro e outro, subtrai-se a violência, e altera a reação de Vidigal. Seu medo de Chico-Juca é evidente, o narrador o chama de 
"desespero do Vidigal". Quanto a Leonardo, o medo se limita a ser desmoralizado, a ver desmontar sua, do major, imagem de chefe supremo da ordem. Salvo engano, Chico-Juca, o profissional da rixa, está fora do alcance do espírito rixoso. Para ele, rixa é coisa séria, e se Vidigal pudesse lhe dar uma "solução definitiva", daria $^{10}$, não haveria maiores problemas em suprimi-lo.

Peço paciência para uma última mediação antes de voltarmos à possibilidade inicial, de lermos as Memórias de um sargento de milícias como um romance de formação brasileiro. Trata-se de uma das molas secretas do romance, que torna impossível uma leitura que não contemple a natureza escravocrata da sociedade brasileira de então. No capítulo IX do primeiro tomo do livro, intitulado "O 'Arranjei-me' do Compadre”, o narrador conta a história de como o padrinho de Leonardo conseguiu montar sua barbearia. No mesmo tom ameno do restante da narrativa, o narrador nos diz que o Compadre se empregou em um navio negreiro e, com a morte do capitão, desviou os valores do tráfico de escravos, se apropriando do pagamento dos marinheiros e da herança da filha do capitão.

Embora pareça uma passagem lateral da narrativa, com o abandono dos pais e, depois, com a morte da Compadre, torna-se central, porque o protagonista vai receber, no final do romance, essa herança ("mil cruzados em espécie"), processada pelo ofício honesto, sim, mas desviada do tráfico negreiro, bom dizer, também atividade legal quando o Compadre embarcou no navio - se recompomos a linha do tempo do romance, o "arranjei-me" se passa no final do século XVIII ou início do século XIX; certamente antes da chegada da família real portuguesa ao Brasil em 1808. A história de Leonardo, aliás, como sabido, transcorre no "tempo do Rei", antes de 1821, portanto, quando a colônia era regida pelas Ordenações Filipinas, que trazem a seguinte passagem no Livro Quinto, Título LXVIII, “Dos Vadios”:

Mandamos, que qualquer homem que não viver com senhor, ou com amo, nem tiver Officio, nem outro mestér, ou ganhe sua vida, ou não andar negoceando algum negócio seu, ou alheo, passados vinte dias do dia, que chegar a qualquer Cidade, Villa ou lugar, não tomando dentro nos vinte dias amo, ou senhor, com quem viva, ou mestér, em que trabalhe, e ganhe sua vida, ou se o tomar, e depois o deixar, e não continuar, seja preso, e açoutado publicamente. (consulta feita em 24/06/2020 da versão fac-similiada mantina on-line pela Universidade de Coimbra $)^{11}$

O ponto aqui é que quando Leonardo briga com sua família - capítulo VI do segundo tomo, "Pior transtorno" -, tornando-se passível de prisão por Vidigal. Antes disso ele está sob a guarda, do ponto de vista legal, do Compadre e depois de Leonardo-Pataca. Na história, é por isso que a Comadre se apressa em lhe

$10 \mathrm{D}$. Maria, única representante da classe proprietária no romance, tampouco toma parte da rixa, mas desenvolver essa leitura fugiria ao escopo do ensaio. Marco, contudo, que concordo com o princípio estruturado por Otsuka no ensaio em questão, mas discordo de sua leitura de que D. Maria e Chico-Juca agiriam segundo o "espírito rixoso".

11 Este título e os títulos seguintes das Ordenações Filipinas precisam ser lidos com cuidado para quem quer entender a atuação de Major Vidigal no romance, o que não cabe recompor aqui. Também cabe considerar o Código Criminal do Império do Brazil (1830), porque o presente do narrador é provavelmente posterior ao código e algumas misturas de tempos, do narrador e do narrado, ocorrem no romance. 
conseguir um "arranjo" na ucharia real. (Esse marco também traz consequências para além da coerência narrativa, fazendo com que acompanhemos antes os embates de Vidigal com o pai do protagonista, numa espécie de duplo.) Nos dois casos, de Leonardo pai e de Leonardo filho, contudo, o limite das ações de Vidigal é notável. Quando o pai é preso em "flagrante delito de nigromancia" e recebe chibatadas antes de se identificar como meirinho, diz o narrador, quando Leonardo sabe que vai ser levado à casa de guarda: "Perdoaria de bom grado as chibatadas que levara, contanto que elas ficassem em segredo; mas ir para a casa da guarda, e dela talvez para a cadeira... isso é que ele não podia tolerar." (Almeida, 2006, p. 95) Tolerando ou não, Leonardo segue para o largo da Sé, se torna assunto dos membros de seu ofício no dia seguinte e é salvo da prisão por intervenção do tenente-coronel. Quando o filho finalmente receberia seu castigo - "não só ficaria por mais tempo preso, como teria de ser chibatado" (Almeida, 2006, p. 317) -, a salvação vem "de baixo", Maria-Regalada, antigo pecado do major, provavelmente uma cortesã, como indica o apelido, oriundo de "regalo", "deleite", intervém a favor do protagonista. Essa salvação é tão definitiva que culmina em promoção, casório e desfecho feliz para o jovem "malandro".

Que essa dialética entre ordem e desordem movimenta boa parte das personagens, o narrador e a forma do livro, é leitura já feita por Antonio Candido - subtraído o rigor da lei, resta a arbitrariedade; quanto mais próxima da elite, o que acarreta também impunidade, essa arbitrariedade tem maior alcance e se reforça de outras qualidades, como o capricho, a perversão etc.; como poderia ser uma leitura de continuidade entre o trabalho de Candido sobre as Memórias de um sargento de milícias e o trabalho de Roberto Schwarz sobre as Memórias póstumas de Brás Cubas. A recuperação dos detalhes trabalha para indicar que os favores do tenente-coronel e a herança do Compadre "fecham o corpo de Leonardo", e de seu pai, para os rigores da lei, e que o romance traz um número não pequeno de personagens que não logram dessa condição. Leonardo, especialmente, não pode ser caracterizado como "homem livre e pobre" (Schwarz, 1987, p. 139) ou homem livre pobre (Otsuka, 2007, p. 118). Mesmo "gente livre modesta", expressão de Candido, não dá conta do grau de proteção do protagonista nem de sua condição de herdeiro - noutro ponto do ensaio, diz o crítico sobre Leonardo: "tão longe da condição servil” (Candido, 2006, p. 20); os cerca de 960 mil reis herdados do Compadre lhe permitiram comprar até sete escravizados nas primeiras décadas do XIX e equivaliam a quase três mil demandas de seu pai em fim de carreira.

Essas personagens fora da rixa, negras e/ou sem ofício, às margens das instituições, não estão distantes o bastante da condição da população escravizada a ponto de ambicionar tratamento coerente à condição de indivíduo livre, sendo demasiado modestas ou não suficientementes livres, bruxuleiam entre a condição de objetos e sujeitos, porque à mercê do arbítrio de qualquer figura empossada da condição de guardiã da ordem: "o major Vidigal era o rei absoluto, o árbitro supremo de tudo que dizia respeito a esse ramo de administração” (Almeida, 2006, p. 91). Mas não se enganem a leitora e o leitor com a condição de rei bufo com que Vidigal é representado - o major Vidigal histórico precisou, inclusive, de doação de monges para conseguir um terreno para construir sua casa. A lei vale e não 
vale para Leonardo, que não é da casa real ("e nesse tempo tal qualidade trazia consigo não pequenas imunidades"), mas ruma para se tornar proprietário. Se necessário, todos sabem que rei manda, e ensaiam, brincam, brigam sobre até onde alcança sua imunidades ou imunidades correlatas.

Um dos mitos do individualismo burguês (Watt,1997), Robinson Crusoe, mesmo na mais inóspita das paragens, leva consigo o cálculo, o rigor, o planejamento e a metodização burgueses. Homero Araújo (2018) aponta que, embora não seja enfocado pela crítica, a condição burguesa do herói inglês está assentada em bases escravocratas brasileiras, com efeito, portuguesas d'além-mar, o que figura na estrutura do romane de Defoe com "um bom senso ameno e amoral, que não aposta meio guinéu na versão meritocrátca do trabalho recompensado” (2018, p. 32). Se é fantástico que os responsáveis cumpram um contrato trinta anos depois e encaminhem os rendimentos de todo esse tempo a Crusoe (Araújo, 2018, p. 32), trata-se da fição modelar do mundo burguês, o contrato, sobre um chão histórico que, observado com agudeza, desmonta as bases da individualidade, da isonomia, da equidade etc. De forma análoga, parece fantástico que Leonardo guarde intacta a herança do filho, mas no caso do romance brasileiro recairia sobre o pai a ira de figuras poderosas ou relativamente poderosas, como D. Maria, a Comadre, talvez o Tenente-Coronel; salvo melhor juízo, o desfecho é menos fantástico nas Memórias do que nas Aventuras. Sublinhando que também nas Memórias de um sargento de milícias não há condenação moral à escravidão, observa Araújo: "assim, há um pitoresco, e um tanto sinistro, encontro entre a estabilidade do herói malandro de Almeida e a propridade do herói burguês de Defoe, ambos às voltas com a sorte que lhes fornece patrimônio advindo dos negócios escravistas" (2018, p. 33). Talvez a noção de romance de formação nos auxilie a precisar esse encontro.

Com o perdão da síntese, que exigira um ensaio exclusivo para ser devidamente mediada, Robinson Crusoe ensina a levar para todo o canto o espírito burguês. Não são raras as passagens na narrativa - seria possível dizer até mesmo que são muito repetitivas - em que Crusoe é salvo por ser precavido, ordenado, metódico, observador, racional, previsível. Este é o centro do quadro, mas nas margens encontramos a propriedade escravista "nos Brasis" (como é referido no romance), responsável pela aventura do protagonista e, no desfecho, por uma maturidade confortável ${ }^{12}$. Memórias de um sargento de milícias, por sua vez, ensina que contratos existem para serem burlados - uma das bases folclóricas da romance é a lenda de Pedro Malasartes, cuja versão mais recorrente gira em torno de uma arguta subversão contratual. O protagonista segue adiante pelos favores de que se vale, pela manipulação das pessoas em seu entorno, resguardado pela proteção do figurão e pela herança. Iniciativas pessoais de operar seu próprio destino fazem água. É melhor

12 De passagem, liberalismo e escravidão não aparecem em Crusoe representados como incompatíveis. Como sabemos, não é. Liberalismo e escravidão parecem incompatíveis num mesmo lugar, num mesmo tempo, quando divisados por uma perspectiva que entenda e apreenda o absurdo - a leitura schwarziana de Machado de Assis, por exemplo. Uma das definições de liberalismo poderia ser "colocar a escravidão em outro lugar"; a questão é que nós éramos esse outro lugar, com governantes e elites frequentando e professando o ideário liberal. O capitalismo corrente impõe a coexistência entre liberalismo/neoliberalismo e escravidão / uberização / precarização e não se entendem essas relações como incompatíveis, mas como intrínsecas; o que já estava de certa forma sugerido no romance de Defoe. 
não fazer nada, como diria com todas as letras o narrador de "O medalhão", de Machado de Assis, um pouco mais adiante. As oportunidades devem ser abraçadas com todas as forças, pois a falta de regularidade indica que o provável é que não apareçam de novo, como Vidinha ouve de sua mãe. A condição objetal da escravidão, que, então, "modela, ao fim e ao cabo, toda subjetividade no Brasil, de todos os níveis sociais" (Pasta Júnior, 2010, p. 6), é consequência das materialidades do centro do mundo, não excrescência. Crusoe, no "tempo do rei", seria tido por ingênuo. Salvo engano, não há representação acabada de nenhum indivíduo burguês no romance de Almeida, tal como representado às pencas, mesmo em personagens secundárias, de romances ingleses e franceses do XIX. Se a materialidade nos coloca na condição de "capitalismo a reboque", ao menos nas mãos de boas e bons romancistas nos livra das ideologias mais evidentes, que não resistem a qualquer observação continuada da perspectiva de cá. A escravidão ocupa a margem do quadro em Crusoe; as margens do quadro são o centro da representação das Memórias de um sargento de milícias, com a agravante de o nosso centro mais próximo, Portugal, seja uma corte não liberal num mundo hegemonicamente liberal (Fragoso \& Tolentino, 2001). "Deus mesmo, quando vier, que venha armado", súmula da ideológica superioridade jagunça, na voz de Riobaldo - não por acaso, baliza literária final dessa disjunção, na abertura da segunda metade do século passado (Pasta, 2010), às vésperas de uma nova ordem do mundo.

Se foram feitas objeções neste ensaio às leituras de Candido, Schwarz e Otsuka, eles mesmos nos ensinam que objeção é acumulação na crítica materialista, ainda mais se pertinentes. Candido minora a presença escravocrata no romance de Almeida, o que é corrigido por Otsuka. Ao mesmo tempo, Candido parece indicar o extrato social de Leonardo de maneira mais precisa do que seus sucessores, Schwarz e Otsuka, embora talvez valesse pesar um pouco mais a mão contra a "modéstia" do protagonista. A acurácia do autor de "Dialética da malandragem" se mostra mais uma vez numa passagem lateral, em que parece apontar para esse estado de semi-individuação da sociedade brasileira, se compararmos a um trecho do ensaio de Benjamin, "O Flâneur", não mencionado por Candido explicitamente. Eis a passagem:

De fato, para compreender um livro como as Memórias convém lembrar a sua afinidade com a produção cômica e satírica da Regência e primeiros anos do Segundo Reinado (...). Ambos [dois "jornaizinhos cômicos e satíricos"] se ocupavam de análise política e moral por meio da sátira dos costumes e retratos de tipos característicos, dissolvendo a individualidade na categoria, como tende a fazer Manuel Antônio. Esta linha (...) manifestava-se ainda na verdadeira mania do retrato satírico, descrevendo so tipos da vida quotidiana, que, sob o nome de fisiologia (por psicologia), pululou na imprensa francesa entre 1830 e 1850 e dela passou à nossa. Embora Balzac a tenha cultivado com grande talento, não é preciso recorrer à sua influência, como faz um estudioso recente, para encontrar a fonte eventual de uma moda que era pão quotidiano dos jornais. (Candido, 2004, p. 26)

No parágrafo subsequente, Candido cita Araújo Porto-Alegre, Martins Pena e parte da produção de Joaquim Manuel de Macedo, "cheia de infra-realismo e 
caricatura”. Recuperando a abertura de "O Flâneur", Benjamin diz que o momento áureo dos fisiologistas teria sido nos anos 1840 e que Baudelaire teria passado ao largo da produção. "Em 1841 contavam-se 76 novas fisiologias. A partir desse ano, o gênero decaiu, com a monarquia burguesa, também ele desapareceu. Era um gênero radicalmente pequeno-burguês" (Benjamin, 2000, p. 34). O nó é complicado e não poderá ser desfeito aqui, mas vale puxar algumas linhas. Num primeiro plano, temos evidentemente a influência cultural francesa no Rio de Janeiro. Em seguida, uma primeira tensão profícua em que um "gênero radicalmente pequeno-burguês", florescendo na monarquia burguesa que sucede a aristocracia mais próxima ao Antigo Regime na França, aqui se torna produção de uma sociedade centrada na corte de uma monarquia constitucional em que "liberais desejavam ampliar a esfera do poder legislativo em detrimento do rei" (Costa, 1999, p.138). Uma pequena burguesia composta majoritariamente do funcionalismo público em que o horizonte, mesmo de profissionais liberais, era conseguir uma presidência de província, um lugar na assembleia? E quanto mesmo que essa condição propensa ao fisiologismo e à caricatura começa a se desfazes? Poderíamos avançar na condição de não flâneur de Leonardinho - "O homem da multidão", de Poe, é de 1840 - e reforçar sua condição de Crusoe às avessas - o romane de Defoe é de 1719. Ou ainda pensar que as fisiologias estão para Manuel Antônio de Almeida como Sterne está para Machado de Assis, indicando que não se trata de tomar por referência obra de antanho, mas de perceber, ou não perceber, a ironia em mobilizar uma forma antiga para nos representar no presente. No limite de absurdo, propor que discriminemos e ensaiemos um sem número de diferenças eloquentes entre Jean Valjean e Javert, de Os miseráveis (1862) - lembro que Balzac é citado, como fisiologista, no trecho de Candido -, e Leonardinho e Vidigal, das Memórias; sobretudo as duas figuras da ordem cujos desfechos, no Sena e nas saias, falam por si.

Que século é o nosso "século sério"? A seriedade para nós é cômica? Essa pergunta não lançada ao vento da falta de história, mas modulada: seria cômica nossa seriedade em Martins Pena, Manoel Antônio de Almeida e Machado de Assis? Que nome dar às Memórias de um sargento de milícias, senão realismo, entendido como "conhecimento e exposição das contradições do capitalismo (Cara, 2009, p. 224)? Um realismo que ensina, não pela cartilha da sequência de cenas, de etapas da formação de um indivíduo, que "ninguém aprende samba no colégio"13 , mas pelo dinamismo constante, pelo rocambolesco, pela diferenciação a todo momento, pela rixa, que não transforma a rivalidade entre pares em lutas de classes, mas que classes? Quais? Que revoluções são factíveis na periferia do capitalismo? Aos homens livres remediados, é seguir em frente, entre favores e heranças, sem querer em demasia, que "o ótimo é inimigo do bom”, sem sequer divisar a condição de indivíduo, posto que inadequada nos Brasis. Uma formação reacionária, por suposto, em que toda a agitação se resume à manutenção das forças. Uma educação para o mesmo, para o compasso de espera do que possa ir ou vir pelos portos. 


\section{Bibliografia}

" Almeida, Manuel de Antônio (2006). Memórias de um sargento de milícia (Apresentação e notas de Mamede Mustafa Jarouche). Cotia, SP: Ateliê Editorial.

" Arantes, Paulo Eduardo (1992). Sentimento da dialética na experiência intelectual brasileira: dialética e dualidade segundo Antonio Candido e Roberto Schwarz. Rio de Janeiro: Paz \& Terra.

"Araújo, Homero Vizeu (2018). Variados mas combinados: ensaios sobre literatura. Porto Alegre: Editora da UFRGS.

"Benjamin, Walter (2000). Obras escolhidas Volume III. Charles Baudelaire, um lírico no auge do capitalismo (trad. José Carlos Martins Barbosa e Hemerson Alves Batista). São Paulo: Editora Brasiliense.

"Boucinhas, André. (2016) Ascensão social no romance brasileiro do segundo reinado. (Tese de doutorado). Universidad Federal de Río Grande del Sur.

"Candido, Antonio (2004). "Dialética da malandragem, in cidade [ 3 a ed.] Rio de Janeiro / São Paulo: Ouro sobre Azul / Duas Cidades.

" Cara, Salete de Almeida (2009). Marx, Zola e a prosa realista. São Paulo: Ateliê Editorial.

"Costa, Emília Viotti da (1999). Da monarquia à república: momentos decisivos [6ª̨ed.]. São Paulo: Fundação Editora da Unesp.

"Fragoso, João \& Florentino, Manolo (2001). O arcaísmo como projeto: mercado atlântico, sociedade agrária e elite mercantil em uma economia colonial tardia: Rio de Janeiro, c.1790-c.1840 [4aed. revista e ampliada]. Rio de Janeiro: Civilização Brasileira.

" Gallagher, Catherine (2009)."Ficção", in Moretti, Franco. O romance, vol. I: A cultura do romance (trad. de Denise Bottmann) (p. 629-658). São Paulo: Cosac \& Naify.

" Jarouche, Mamede Mustafa (2006). "Galhofa sem Melancolia: as Memórias num mundo de luzias e saquaremas", in Almeida, Manuel de Antônio. Memórias de um sargento de milícia (p.13-59) Cotia, SP: Ateliê Editorial.

"Lukács, Georg (2000). A teoria do romance: um ensaio histórico-filosófico sobre as formas da grande épica (tradução, posfácio e notas de José Marcos Mariani de Macedo). São Paulo: Duas Cidades / Ed. 34.

"Matos, Claudia (1982). Acertei no milhar: samba e malandragem no tempo de Getúlio. Rio de Janeiro: Paz e Terra.

" Otsuka, Edu Teruki (2007). "Espírito rixoso: para uma interpretação das Memórias de um sargento de milícias", in Revista do IEB (n-44), p.105-124.

"Pasta Júnior, José Antônio (2010). "Volubilidade e ideia fixa: o outro no romance brasileiro", in Sinal de Menos, vol 2, (no-4), p.13-25.

"Pinto, Luiz Maria da Silva (1832). Dicionário da língua brasileira por Luiz Maria da Silva Pinto natural da Provincia de Goyaz. Ouro Preto: Typographia de Silva.

"Silva, Antonio de Moraes \& Bluteau, Rafael (1789). Dicionário de língua portugueza composto pelo padre D. Rafael Bluteau, reformado e accrescentado por Antonio de Moraes Silva natural do Rio de Janeiro. Lisboa: Officina de Simão Thaddeo Ferreira.

"Schwarz, Roberto (1987). "Pressupostos, salvo engano, de 'Dialética da 
Memórias de um sargento de milícias: ninguém...

malandragem"', in Que horas são?: ensaios. São Paulo: Companhia das Letras.

"Xavier, Ismail (2014). Alegorias do subdesenvolvimento: Cinema Novo, Tropicalismo, Cinema Marginal. São Paulo: Cosac Naify.

"Watt, Ian (1997). Mitos do individualismo moderno: Fausto, Dom Quixote, Dom Juan, Robinson Crusoe (trad. Mario Pontes). Rio de Janeiro: Jorge Zahar Editora. 